\title{
EWSR1/ETV4 Fusion Protein
}

National Cancer Institute

\section{Source}

National Cancer Institute. EWSR1/ETV4 Fusion Protein. NCI Thesaurus. Code C99263.

A fusion protein (478 aa. $52 \mathrm{kDa}$ ) encoded by the EWSR1/ETV4 fusion gene. This protein is comprised of the transactivation domain of the RNA-binding protein EWS followed by ETS DNA binding domain of the ETS translocation variant 4 protein. 